\title{
Immunological Detection of a GarV-Type Virus in Argentine Garlic Cultivars
}

\author{
Marcelo Helguera, Instituto de Investigaciones en Ingeniería Genética y Biología Molecular (INGEBI-CONICET), \\ Vuelta de Obligado 2490, 1428, Buenos Aires, Argentina, and Instituto de Fitopatología y Fisiología Vegetal \\ (IFFIVE-INTA), Camino 60 Cuadras Km 5 1/2, CP 5014, Córdoba, Argentina; Fernando Bravo-Almonacid, \\ INGEBI-CONICET and FCEyN-UBA; Ken Kobayashi, INGEBI-CONICET and FCEyN-UBA; Pablo D. \\ Rabinowicz, INGEBI-CONICET and FCEyN-UBA; Vilma Conci, IFFIVE-INTA; and Alejandro Mentaberry, \\ INGEBI-CONICET and FCEyN-UBA
}

\begin{abstract}
Helguera, M., Bravo-Almonacid, F., Kobayashi, K., Rabinowicz, P. D., Conci, V., and Mentaberry, A. 1997. Immunological detection of a GarV-type virus in Argentine garlic cultivars. Plant Dis. 81:1005-1010.

A cDNA library representing the genomes of several garlic viruses was generated using a viral RNA mixture as template. Analysis of randomly selected clones allowed the identification of different viral genomic sequences. On the basis of amino acid and nucleotide sequence comparisons, one of them was assigned to garlic virus A (GarV-A), a novel flexuous, rod-shaped virus recently reported in Japan. The coat protein (CP) of this virus was expressed in Escherichia coli cells and used as immunogen to produce polyclonal antibodies. The expression protein was recognized by an antiserum detecting garlic mite-borne filamentous virus, but did not react with antibodies specific for other garlic viruses. Antibodies raised against the viral CP reacted with extracts infected with garlic mite-borne viruses and fail to recognize preparations of onion yellow dwarf potyvirus, leek yellow stripe potyvirus, and carnation latent carlavirus. The same antibodies decorated viral particles exhibiting a modal length of $586 \mathrm{~nm}$ in immuno electron microscopy with decoration assays. Double-antibody enzyme-linked immunosorbent assays and tissue printing assays performed with these antibodies allowed detection of GarV-A in most garlic cultivars used in Argentina.
\end{abstract}

Commercial garlic varieties are strictly apomixic. For this reason, viruses tend to accumulate in bulb-seed stocks and are readily transmitted to propagative materials $(28,29)$. Disease is caused by a viral mixture-the "garlic viral complex"comprising potyviruses (25), carlaviruses (24), and several flexuous mite-borne viruses that remain unassigned $(23,27)$. The composition of this infective complex varies according to different geographical regions, and usually includes viruses from more than one group $(2,7,8,9,20,22,23,25)$. Symptoms resulting from infection include leaf mosaics and pronounced decreases in the weight and quality of cloves (29).

Several components of the garlic infective complex have been identified on the basis of physical and serological evidence. These viruses include the garlic strains of onion yellow dwarf potyvirus (OYDV-G; 14,25) and leek yellow stripe potyvirus (LYSV-G; 25,32), shallot latent carlavirus (SLV; 28,30), garlic common latent car-

Corresponding author: A. Mentaberry
E-mail: amenta@proteus.dna.uba.ar

This work was partially supported by grants SECyT 2466/92 and CABBIO 009/006/94.

Accepted for publication 16 May 1997.

Publication no. D-1997-0627-01R

(C) 1997 The American Phytopathological Society lavirus (GCLV; 24) and several mite-borne viruses $(27,31)$. Two viruses belonging to this latter viral type were initially classed into the Rymovirus genus of Potyviridae due to their morphological and cytopathological properties (27). Later, it was shown that these viruses were immunologically related to shallot virus $\mathrm{X}$ (ShVX; 13), which also remains unassigned (26). In addition, Sumi et al. (22) obtained partial genomic sequences corresponding to four flexuous garlic viruses (GarV-A, -B, -C, and -D) exhibiting a genomic organization similar to that of ShVX. More recently, Tsuneyoshi and Sumi (23) showed that GarV-C and -D have a close serological relationship with the garlic mite-borne viruses described by Van Dijk et al. (27). All this suggests that garlic mite-borne viruses do not belong to the Rymovirus genus and should be grouped together with the GarV-type viruses (18).

Garlic viruses are unable to infect (or infect very poorly) most alternative host plants (25). As a result, they have been difficult to isolate from each other. Consequently, their classification by criteria commonly accepted in plant virology, such as host-range, morphology, serology, and cytopathology, frequently led to taxonomic confusion. The difficulties of obtaining purified viral proteins limited the production of reliable antisera in the amounts needed for indexing programs or epidemi- ological studies. Application of molecular biology techniques to the study of this viral complex has allowed an increased understanding of the identity of its individual members $(14,20,22,23)$ and the development of specific diagnostic tools.

Current programs for certification of garlic seed-bulbs emphasize the incidence of OYDV-G and LYSV-G in symptom development and yield losses (15). In contrast, the effect of mite-borne and GarVtype viruses on garlic production remains largely unexplored. Taking into account that these viruses have been detected in countries so distant from each other as Argentina, Japan and the United Kingdom $(23,27)$, their significance might be more relevant than previously considered. In this work, the coat protein $(\mathrm{CP})$ gene of a local GarV-A strain was cloned and expressed in Escherichia coli cells, and the respective polypeptide was used to produce polyclonal antibodies in rabbits. These antibodies were successfully employed to optimize double-antibody enzyme-linked immunosorbent assays (DAS-ELISA) and tissue printing immunoassays, and to detect this virus in most of the important garlic cultivars grown in Argentina.

\section{MATERIALS AND METHODS}

Plant material and virus strains. Healthy garlic plants (Allium sativum L. cv. Blanco Mendoza) were obtained from in vitro-cultured meristem tips that were previously subjected to thermotherapy (7). Infected garlic plants (cv. Blanco Mendoza) reacting with antibodies directed to LYSV, OYDV, GCLV, and mite-borne viruses were collected from a production field in Córdoba (central Argentina). Onion (A. cepa L. cv. Ebenezer) and leek (A. ampeloprasum $\mathrm{L}$. var. porrum) plants were grown from seeds obtained from INTA-La Consulta (Mendoza, Argentina). Commercial Dianthus barbatus seeds were purchased from Dinatale (Argentina). Garlic plants infected with mite-borne viruses were grown from thermotherapytreated meristem tips. Only those plants reacting with anti-garlic mite-borne filamentous virus (GMbFV) antisera (2) and showing no reaction with antibodies against OYDV, LYSV, common latent carlavirus (CLV), GCLV, and SLV were considered for this purpose. LYSV-infected leek plants, OYDV-infected onion plants, 
and CLV-infected Dianthus barbatus plants were obtained by inoculation of healthy plants with the respective viruses. Viral infection was confirmed by immuno-electron microscopy with decoration (IEM-D) assays conducted with antibodies specific for LYSV, OYDV, and CLV .

Virus purification. Ten plants of Allium sativum (cv. Rosado Paraguayo) exhibiting typical symptoms of virus infection were sampled from a production field. Several leaves from each plant were mixed and used as a source for virion purification. Isolation of viral particles was carried out according to the procedure described by Murphy et al. (19), with minor modifications. Viral RNA was extracted using the method described by Hull (12) and electrophoresed in denaturing agarose gels. After staining with ethidium bromide, an RNA smear ranging from 10,000 to $7,000 \mathrm{nu}-$ cleotides was visualized. Samples of individual viruses to be analyzed in Western immunoblots were obtained as follows: 20 $\mathrm{g}$ of infected garlic leaves were homogenized in $40 \mathrm{ml}$ of $0.5 \mathrm{M} \mathrm{Na}_{2} \mathrm{~B}_{4} \mathrm{O}_{7}, 0.2 \%$ thioglycolic acid, $\mathrm{pH} 8$, and thoroughly mixed with $10 \mathrm{ml}$ of chloroform. After centrifugation for $15 \mathrm{~min}$ at $7,000 \times \mathrm{g}$, the supernatant was loaded onto a $20 \%$ sucrose cushion and centrifuged for $1 \mathrm{~h}$ at 100,000 $\times g$. Pellets containing approximately 0.2 to $0.5 \mathrm{mg}$ of protein were resuspended in $100 \mu \mathrm{l}$ of $0.05 \mathrm{M} \mathrm{Na}_{2} \mathrm{~B}_{4} \mathrm{O}_{7}, \mathrm{pH} 8$.

Molecular cloning. Synthesis of cDNA was carried out using a mix of viral genomic RNAs as template (see previous section), and oligo(dT) $)_{15}$ as primer for reverse transcription. A cDNA library was obtained using the commercial kit Librarian (Invitrogen Corp., San Diego, CA). Viral cDNA was ligated to BstXI adapters, inserted into the cloning vector pcDNA II, and used to transform E. coli JM 109 cells. Subsequently, 50 recombinant plasmids were digested with BstXI and analyzed in agarose gels to assess the size of the respective cDNA inserts, and those containing the largest fragments were partially sequenced. The $\mathrm{CP}$ gene sequence encoded in clone pCC6 was amplified by polymerase chain reaction (PCR) using two oligonucleotide primers designed on the basis of the sequence deduced from this clone (5'-ATAGGATCCCATATGAACGCACCTGTTGAC-3' and 5'-GTAACTTGAATTCTAGAGGAATCATC-3'), which introduced a BamHI site at its $5^{\prime}$ end (underlined sequence). The PCR was carried out in a $100 \mu \mathrm{lmix}$ containing $1 \mathrm{ng}$ of plasmid pCC6, $1.5 \mathrm{mM}$ of $\mathrm{MgCl}_{2}$ and 200 ng of each primer. Nucleotide buffer and Taq polymerase were obtained from Promega (Madison, WI). The amplification program consisted of 5 cycles of $1 \mathrm{~min}$ at $94^{\circ} \mathrm{C}, 1 \mathrm{~min}$ at $50^{\circ} \mathrm{C}, 2 \mathrm{~min}$ at $72^{\circ} \mathrm{C}$; and 30 cycles of $1 \mathrm{~min}$ at $94^{\circ} \mathrm{C}, 1 \mathrm{~min}$ at $60^{\circ} \mathrm{C}$, $2 \mathrm{~min}$ at $72^{\circ} \mathrm{C}$. After completion of the reaction, the PCR products were electrophoresed in a $1.2 \%$ agarose gel and visu- alized by staining with ethidium bromide. The DNA fragment corresponding to the $\mathrm{CP}$ gene was purified from the gel using Wizard PCR Preps (Promega), blunted with T4 DNA polymerase (Gibco BRL, Gaithersburg, MD) and digested with BamHI. The fragment was then subcloned by $B a m H I / b l u n t$ end ligation into the $E$. coli vector pRSETa (Invitrogen), which allowed expression of the viral protein as a C-terminal fusion to a poly-hystidine tract. The resulting plasmid was called pRSET/ C6CP.

DNA sequencing and recombinant DNA techniques. Nucleotide sequencing was performed by the dideoxy chain-termination method (21) using a commercial kit (Sequenase US Biochemical, Cleveland, $\mathrm{OH}$ ). Sequencing was conducted according to instructions provided by the manufacturer. At least two independent sequences from both the sense and antisense DNA strands were obtained. Comparisons between nucleotide and amino acid sequences were made using the Prosis Maxim Homology program (Hitachi Software, Japan). The sequence reported in this paper is listed under GeneBank accession No. X98991. DNA digestions, electrophoresis, hybridizations, and other recombinant DNA procedures were conducted as described in Maniatis et al. (16) and Ausubel et al. (1).

Viral protein expression and purification from bacterial cells. Plasmid pRSET/C6CP was introduced into E. coli BL21 pLys cells by a standard transformation procedure (16). Expression of the $\mathrm{C} 6 \mathrm{CP}$ polypeptide was induced by addition of $0.3 \mathrm{mM}$ IPTG to a bacterial culture grown to $\mathrm{OD}_{600} 0.5$ and by further incubation for $2 \mathrm{~h}$ at $37^{\circ} \mathrm{C}$. The $\mathrm{C} 6 \mathrm{CP}$ protein formed intracellular aggregates that could be easily precipitated from cell extracts. Bacterial cells were resuspended in STE buffer $(100 \mathrm{mM} \mathrm{NaCl}, 50 \mathrm{mM}$ Tris- $\mathrm{HCl}$, $\mathrm{pH} 8,1 \mathrm{mM}$ EDTA), disrupted by sonication and centrifuged for $10 \mathrm{~min}$ at $9,000 \times$ $g$. The resultant pellet was resuspended in $2 \mathrm{ml}$ of STE buffer supplemented with 8 $\mathrm{mM} \mathrm{MgCl} 2,10 \mu \mathrm{g} / \mathrm{ml}$ DNase I, and maintained for $15 \mathrm{~min}$ at $4^{\circ} \mathrm{C}$. The incubation mix was centrifuged for $10 \mathrm{~min}$ at $9,000 \times$ $g$ and the pellet was resuspended in $1 \mathrm{ml}$ of STE buffer. Expression products were analyzed in Western immunoblots using antibodies specific for the different garlicinfecting viruses.

Rabbit immunization. Bacterially expressed C6CP protein was electrophoresed in a preparative SDS-polyacrylamide gel and the C6CP band was excised from the gel, crushed and lyophilized. Antisera were produced in two California female rabbits by intradermal injection of $0.6 \mathrm{mg}$ of fusion protein emulsified in $1 \mathrm{ml}$ of Freund's complete adjuvant (Sigma Chemical Co., St. Louis, MO). Two weeks later, each animal was boosted by intramuscular injection of an equal amount of protein in
Freund's incomplete adjuvant. Bleeding was conducted at 15 and 21 days after the last injection. Anti-C6CP antiserum was used at a 1:2,000 dilution.

Antisera and immunoassays. The antiOYDV and anti-LYSV antisera were provided by K. Graichen (Institute fur Pathogendiagnostik, Germany) and Dr. H. Lot (INRA-Montfavet, France), respectively. The anti-SLV antiserum was obtained from D. Maat (Research Institute for Plant Protection, The Netherlands), and antisera recognizing GCLV and GMbFV (2) from D. Lesemann (Federal Biological Research Centre for Agriculture and Forestry, Germany). The antiserum against CLV was obtained from E. Luisoni (Instituto di Fitovirologia Applicata, Italy). Antibodies recognizing multiple components of the garlic viral complex (anti-GVCx) were obtained by standard procedures at IFFIVE-INTA, using a mixture of purified garlic viruses as a source of antigen. Purification of the $\mathrm{IgG}$ fraction was carried out by $\left(\mathrm{NH}_{4}\right)_{2} \mathrm{SO}_{4}$ precipitation followed by fractionation in a DEAE-Sepharose chromatography column (Pharmacia LKB Biotechnology, Inc., Uppsala, Sweden). Alkaline phosphatase-IgG antibodies were obtained by coupling with glutaraldehyde following the procedure reported by Harlow and Lane (11). DAS-ELISAs were performed according to Clark and Adams (6).

Tissue printing. Cloves from chronically infected bulbs were transversely or longitudinally cut with a scalpel blade and printed onto BA85 nitrocellulose membranes (Schleicher and Schuell, Dassel, Germany). The membranes were blocked for $1 \mathrm{~h}$ at room temperature in $50 \mathrm{mM}$ Tris$\mathrm{HCl}, \mathrm{pH} 8,150 \mathrm{mM} \mathrm{NaCl}, 1 \%$ Tween 20 and $5 \%$ not-fat dried milk, washed three times in $50 \mathrm{mM}$ Tris- $\mathrm{HCl}, \mathrm{pH} 8,150 \mathrm{mM}$ $\mathrm{NaCl}, 0.05 \%$ Tween 20 (TBS/Tween), and incubated for $1 \mathrm{~h}$ in the same buffer supplemented with 5\% not-fat dried milk, $5 \%(\mathrm{wt} / \mathrm{vol})$ extract from healthy garlic plants, and anti-C6CP as primary antibody. The blots were then washed and incubated with alkaline phosphatase-linked goat antirabbit antibody (BioRad, Hercules, CA) for another period of $1 \mathrm{~h}$. Following several washes in TBS/Tween, phosphatase activity was visualized by a chromogenic reaction using nitroblue tetrazolium and 5 bromo-4 chloro-3 indolyl phosphate (Gibco BRL) as substrates (1).

SDS-PAGE and Western blots. Infected leaf tissues and purified virion preparations were resuspended in $60 \mathrm{mM}$ Tris- $\mathrm{HCl}, \mathrm{pH} 6.8,10 \%$ glycerol, $5 \% \beta$ mercaptoethanol, and $0.1 \%$ SDS. Samples were boiled for $5 \mathrm{~min}$ and centrifuged for 2 min at $9,000 \times g$. Total protein content was determined following the method of Bradford (3). Aliquots containing 30 to $40 \mu \mathrm{g}$ of protein were electrophoresed in $12.5 \%$ SDS-polyacrylamide gels that were then stained with Coomassie Blue or blotted 
onto nitrocellulose membranes. Viral proteins were detected by a 1-h incubation with antisera recognizing different garlic viruses as primary antibodies, followed by several washes with TBS/Tween and a second 1-h incubation with alkaline phosphatase-linked goat anti-rabbit antibody as secondary antibody. Following this treatment, phosphatase activity was detected as described above.

Immuno electron microscopy with decoration assays. Decoration assays of viral particles were performed basically as described by Milne and Luisoni (17) using garlic plants infected with OYDV, LYSV, and other non-identified viruses. Briefly, carbon filmed grids (Ernest F. Fullam, Latham, NY) were incubated for $5 \mathrm{~min}$ at $20^{\circ} \mathrm{C}$ in $10 \mu \mathrm{l}$ of anti-GVCx antiserum diluted $1: 500$ to $1: 1000$ in $0.05 \mathrm{M}$ $\mathrm{Na}_{2} \mathrm{~B}_{4} \mathrm{O}_{7}, \mathrm{pH}$ 8. Antiserum-coated grids were washed with $2 \mathrm{ml}$ of $0.05 \mathrm{M}$ $\mathrm{Na}_{2} \mathrm{~B}_{4} \mathrm{O}_{7}, \mathrm{pH} 8$, immersed in $100 \mu \mathrm{l}$ of infected plant extracts and kept for $15 \mathrm{~min}$ at $20^{\circ} \mathrm{C}$. Following this, the grids were washed as before and treated with specific antisera at 1:20 dilution in 0.05 M $\mathrm{Na}_{2} \mathrm{~B}_{4} \mathrm{O}_{7}, \mathrm{pH} 8$, for $15 \mathrm{~min}$. After this, the grids were washed with distilled water and stained with $2 \%$ uranyl acetate. Viral preparations were observed at $1200 \times$ in a electron microscope (Jeol, Japan). Size of GarV-A particles was estimated from samples of virus mixtures using the $\mathrm{C} 6 \mathrm{CP}$ antiserum in IEM-D assays. Virion lengths were calculated according to Brandes and Wetter (4) by comparison with spherical latex particles of $0.482 \mu \mathrm{m}$ in diameter (Ted Pella, Redding, CA).

\section{RESULTS}

Cloning of a GarV-type genomic sequences. A mix of virions purified from infected garlic plants was used as the source of RNA to generate a cDNA library. Three clones from this library, pCC5, pCC6, and pCC15, contained cDNA fragments showing $82 \%$ nucleotide sequence homology with GarV-A, a novel rodshaped virus that was recently characterized in Japan (22). Clone pCC6 contained a sequence comprising the complete $\mathrm{CP}$ gene, the $15 \mathrm{kDa} \mathrm{ORF}$, the $3^{\prime}$ non-coding region, and a short poly(A) tract (Fig. 1A to D). A comparison between the pCC6 translated sequences with those corresponding to GarV-A showed homologies of $91 \%$ for the viral CP and $75 \%$ for the 15 kDa polypeptide (Fig. 1B and C). Similar comparisons with the respective sequences of GarV-B, -C and -D showed homologies of 63,61 , and $76 \%$ for the coat protein and 50,53 , and $66 \%$ for the $15 \mathrm{kDa}$ product, respectively. The highest level of nucleotide sequence homology (98\%) was found between the pCC6 and GarV-A 3' noncoding sequences (Fig. 1D).

Bacterial expression of the pCC6 CP gene. The sequence corresponding to the complete pCC6 CP gene was amplified by
PCR and subcloned into the E. coli expression vector pRSETa (plasmid pRSET/ $\mathrm{C} 6 \mathrm{CP}$ ). In agreement with the size predicted from the amino acid sequence, expression of the pCC6 CP gene in bacterial cells led to the production of a $31 \mathrm{kDa}$ fusion protein. This expression protein did not react with antisera specifically recognizing LYSV, OYDV, CLV, SLV, or GCLV, but it was detected by antibodies raised against GMbFV (data not shown). To further explore the identity of the corresponding virus, the $31 \mathrm{kDa}$ protein was used as immunogen to raise polyclonal antibodies. The resulting antiserum (C6CP antiserum) was used to analyze OYDV, LYSV, or CLV virion preparations in Western immunoblots (Fig. 2A). This antiserum did not react with semi-purified prepara-

A

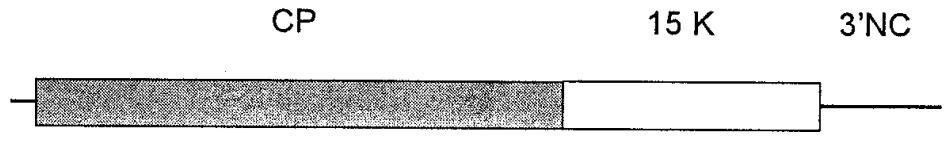

B

PCC6 MNDPVDESTSQOMSGSTSQVSQERENVNEFGQTOLRSLGNRDEQNNSSNASNESDE GaIV-A MNNPVDESTSQQMSGTTGQVSQERENVNEEGQSQTRPLGNRDEQNNS-NASDDSDA LMEALAE EETLTKDVESNSVASRTI IREI LDLLQAKRQGAT PKDLLSLAWTCYHNG LMEAVTDEET LTKDVESNSVASRLI IRD I LDMLOAKRQGAT PKDLFSLAWTCYHNG

SSREVTLTT DAECGMAHSELKDVVEDYCTLRQFCGEYAKACYVTGKQONKPPANWS SSREVTLTT DAFCGMAHSELKDIVENSCTLRQFCGEYAKACYVAGKQQNKE'PANWS

RKGYQEDSKEAAFIEENAVLSDSSENE'GGMREKET DAEI LAHSMNAKMSIVESRR RKGYQEDSKEAAEDEENAVLSDSSESE' GGMREKETDAEILAHSMNAKMSIVESRR

ATNMVSTRADLLAOQOIHEQEKE'MITE (251)

ATNMVSTRADLLAQQQIHEQEKPEMITE (251)

6

PCC6 MIEQDEKLLCCLHEAKETLSQDLKNLLEFICVDECKLIRKASQNKEEQGTSKFAQR GarV-A MIPQDENILCCLHEAKEFIPQDLKAHLEETCVNECKLVRIARENKEELGTSKCAQR

RRAKRYNRCEDCGAYLLDNHKCKVITSRGQSDVLTVIHEGEVKLYAERTYRENSDA RRAKRYNRCEECGAYLLDNHKCRIFVSRAOSDVIAVIHEGEAKLHAERTYRENSDA

ALLIESDLEYIKILKL--- (128)

ALLIESDLQY IKLFQNRKA (131)

D

PCC6 GGCTTGACCAAGCTCOACAGGGTTPACAGGGTTCTGGACGTGGACAAAGACAC GarV-A GGCTTACCOAAGCTCCOACAGGTTTACAGGGTTCTGGACGTGGACAAAGACAC

CCACGATTGTTGATATTGCTAAACTTACCTCGCAACAACTGTTGTCCCCAGTGAC CCACGATTGTTGATATTGCTAAACTTACCTTGCAACAACTATTGTCCCCAGTGAC

Fig. 1. Sequence comparisons between clone pCC6 and the garlic virus A (GarV-A) genome. (A) schematic representation of coding and non-coding nucleotide sequences in clone pCC6. Open boxes represent ORFs encoding the viral coat protein $(\mathrm{CP})$ and to the $15 \mathrm{kDa}$ protein; (B) and (C) amino acid sequence comparison between the CPs $(\mathbf{B})$ and the $15 \mathrm{kDa}$ proteins $(\mathbf{C})$ encoded in clone pCC6 and in the GarV-A sequence; (D) nucleotide sequence comparison between the 3' non-coding sequence of clone pCC6 and the GarV-A genome. GarV-A sequence was taken from Sumi et al. (22). Differences in the amino acid and nucleotide sequences are indicated in bold. 
antibodies to epitopes located in plant proteins.

Immuno-electron microscopy. In order to establish the morphology of the viral particles reacting with the $\mathrm{C} 6 \mathrm{CP}$ antiserum, garlic samples infected with a mixture of different viruses were analyzed in IEM-D assays. A sub-population of flexuous rod-shaped virions strongly reacted with anti-C6CP, while other viral particles were not stained (Fig. 3A). The decorated particles displayed a modal length of $586 \mathrm{~nm}$ (Fig. 3B). Confirming its specificity, the $\mathrm{C} 6 \mathrm{CP}$ antiserum did not react with samples exclusively con- taining OYDV, LYSV, or CLV particles (data not shown).

DAS-ELISA and tissue printing assays. On the basis of the evidence reported above, it was concluded that the cDNA sequence encoded in pCC6 corresponded to a local strain of GarV-A, and that the C6CP antiserum showed high specificity to this virus. To study its performance in DAS-ELISA tests, the C6CP antiserum was tested against serial dilutions of plant extracts infected with either garlic miteborne viruses, OYDV, or CLV. While extracts infected with mite-borne viruses reacted with anti-C6CP at dilutions ranging

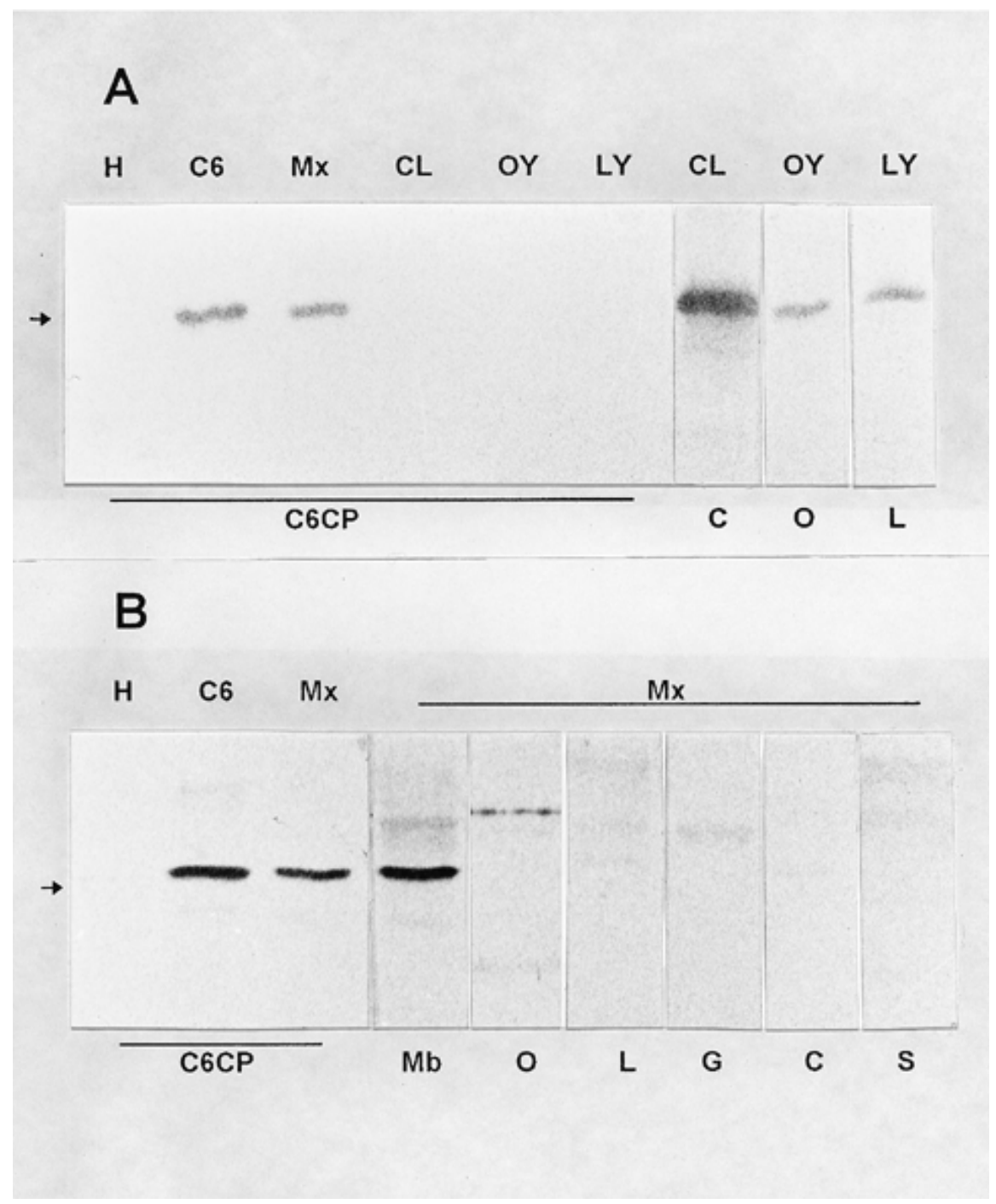

Fig. 2. Western blot analysis of partially purified virion preparations with antisera recognizing different garlic-infecting viruses. (A) immunoblots of partially purified onion yellow dwarf potyvirus (OYDV), leek yellow stripe potyvirus (LYSV), and carnation latent carlavirus (CLV) virions developed with C6CP antiserum. (B) immunoblots of partially purified mite-borne virions developed with antisera recognizing different garlic-infecting viruses. $\mathrm{H}=$ extract from healthy garlic plants; $\mathrm{C6}$ $=$ recombinant $\mathrm{C} 6 \mathrm{CP}$ expression protein; $\mathrm{Mx}=$ semi-purified virions from garlic plants infected with mite-borne viruses; CL, OY, LY = semi-purified virions from CLV-, OYDV-, and LYSV-infected plants, respectively. Each lane was loaded with $30 \mu \mathrm{g}$ of protein. The antisera used in each case are indicated at the bottom of the panel. $\mathrm{O}=$ anti-OYDV; $\mathrm{L}=$ anti-LYSV; $\mathrm{G}=$ anti-GCLV; $\mathrm{C}=$ anti-CLV; $\mathrm{S}=$ anti-SLV; $\mathrm{Mb}=$ anti-GMbFV. All antisera were employed at dilutions of 1:2,000. The arrow indicates the position of the $30 \mathrm{kDa}$ molecular marker. Membrane cuts shown in (A) and (B) correspond to different gels.

from $1: 1,000$ to $1: 2,000$, only background values were observed in the case of plants infected with OYDV or CLV. Reciprocally, anti-OYDV and anti-CLV antisera did not react with extracts containing garlic miteborne viruses (data not shown). Therefore, DAS-ELISA results closely correlated with those obtained by Western blot analysis, suggesting that anti-C6CP could be included in routine diagnostic tests for de-
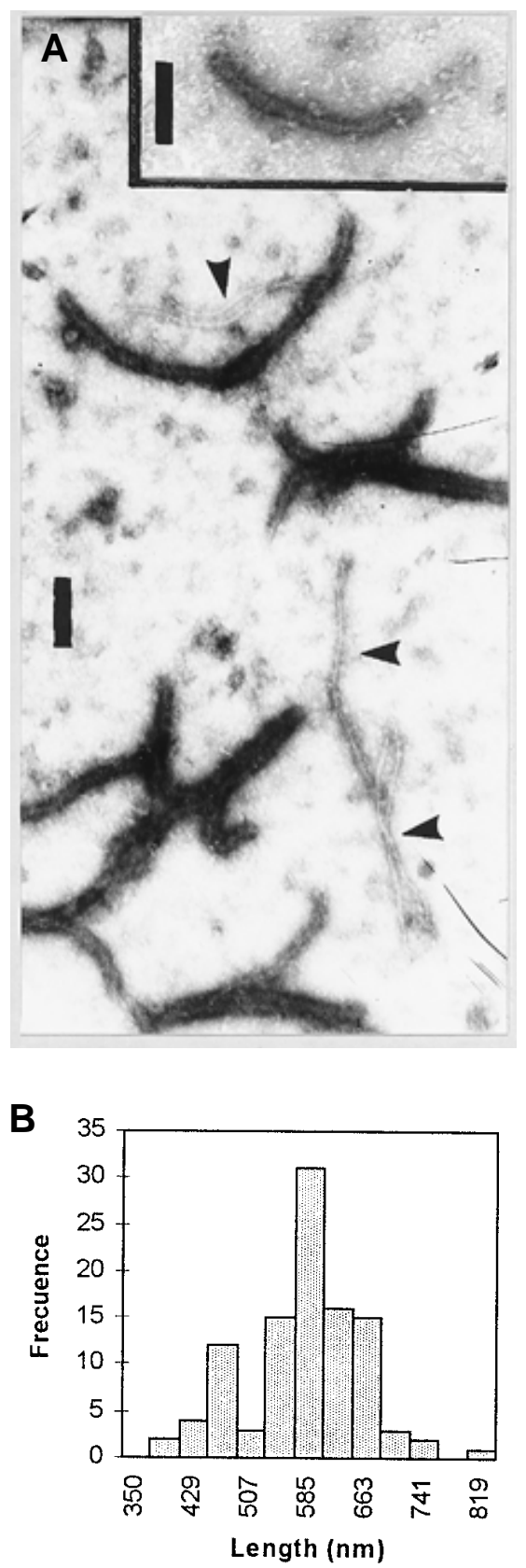

Fig. 3. Morphological characteristics of virions recognized by anti-C6CP antibodies. (A) immuno-electron microscopy with decoration (IEM-D) assay of garlic viruses reacting with anti-C6CP antiserum. Non-decorated particles are indicated by solid arrowheads. An individual viral particle decorated by anti-C6CP is shown in the insert. Scale bars indicate $200 \mathrm{~nm}$. (B) length distribution histogram of viral particles recognized by the C6CP antiserum. A total of 105 viral particles grouped in ranges of 39 nm were measured. 
tection of GarV-A. Preliminary DASELISA tests performed with samples from different garlic production areas indicated that this virus is present in all commercially important varieties grown in Argentina (cv. Rosado Paraguayo, Blanco Mendoza, and Colorado Mendoza).

In order to study the distribution of GarV-A viruses in chronically infected garlic plants, the C6CP antiserum was used to perform a series of squash blot and tissue print immunoassays. Viral presence could be easily detected in squash blots of leaves and roots from infected plants (data not shown). Interestingly, strong binding of anti-C6CP antibodies was observed in tissue printings from individual cloves or whole bulbs (Fig. 4A and B), suggesting that this technique could be advantageously developed to monitor viral presence in propagative materials.

\section{DISCUSSION}

Due to problems derived from their narrow host range, individual viruses of the garlic complex have been difficult to isolate employing the traditional tools of plant virology. On the other hand, simultaneous cloning of viral genomes, and subsequent analysis of the respective cDNA libraries, provided a suitable means to study the composition of this complex in different geographical locations. The feasibility of such an approach was shown by Sumi et al. (22) and Nagakubo et al. (20) in Japan, and by ourselves in Argentina (14). In our case, analysis of randomly selected cDNA clones allowed characterization of partial genomic sequences derived from three different viruses. While two of them were assigned to OYDV-G (13) and LYSV (unpublished results), the third sequence is identified here as belonging to a local strain of GarV-A. No sequences showing features typical of the genome organization of carlaviruses were isolated in this first screening of our cDNA library.

The sequence encoded in plasmid pCC6 was assigned to GarV-A on the basis of sequence comparisons (22) and immunological evidence. Amino acid sequence comparisons demonstrated $91 \%$ homology between the CPs of pCC6 and GarV-A, while similar comparisons with GarV-B, $-C$, and -D showed homology values of 63 , 61 , and $76 \%$, respectively. A lower degree of homology $(75 \%)$ between pCC6 and GarV-A was found in the case of the 15 $\mathrm{kDa}$ product. In particular, the pCC6 sequence lacked three amino acids at the $\mathrm{C}$ terminus, as compared with the sequence reported by Sumi et al. (22). This difference was ascribed to the genomic heterogeneity that is usually present in wild viral populations. On the other hand, nucleotide sequence comparisons showed much higher sequence homology between the $3^{\prime}$ non-coding regions, which is commonly observed among different strains of the same virus (10).
The antigenic properties of the C6CP polypeptide and the specificity of the C6CP antiserum provided further support to the notion that GarV-type and garlic mite-borne viruses are closely related. Thus, while the C6CP polypeptide was recognized by anti-GMbFV antibodies, it was not detected by antibodies against OYDV, LYSV, SLV, GCLV, or CLV. On the other hand, the $\mathrm{C} 6 \mathrm{CP}$ antiserum recognized a protein of about $30 \mathrm{kDa}$ in virion preparations obtained from plants infected with garlic mite-borne viruses, but it failed to react with OYDV, LYSV, and CLV preparations. Similar evidence confirming this relationship was previously postulated in the case of other GarV-type and mite-borne viruses. For example, an anti-GarV-C antibody was able to recognize garlic mite-borne mosaic virus (GMbMV; 23), and GarV-D showed considerable sequence similarity with a novel garlic mite-borne virus recently isolated in England (23).

On the basis of our results, we cannot totally discard the possibility that the C6CP antiserum might recognize more than one GarV sub-type. In this regard, it should be noted that the anti-GarV-C antibodies obtained by Tsuneyoshi et al. (23) cross-reacted with GarV-B, -C, and -D, indicating that these viruses share common antigenic determinants. However, in mixtures including several garlic mite-borne viruses, the $\mathrm{C6CP}$ antiserum decorated a subpopulation of viral particles exhibiting a narrow range of size distribution, suggesting the recognition of a particular GarV-type component. Moreover, it was observed in several IEM-D assays that
anti-C6CP decorated a lower percentage of viral particles than anti-GMbFV, which also implies a high degree of specificity. Therefore, though the $\mathrm{C} 6 \mathrm{CP}$ antiserum might eventually detect other GarV-type viruses, we concluded that it has practical diagnostic value and could be advantageously incorporated with the tests that are currently performed for indexing of propagative materials. Preliminary studies using the C6CP antiserum in DAS-ELISA showed that GarV-A is present in all major garlic cultivars grown in Argentina, with frequencies ranging from 17 to $60 \%$. Additional determinations in a larger scale will be performed to precisely establish the incidence of this virus in different production areas.

Finally, tissue print immunoassays revealed that GarV-A is abundantly present in cloves, suggesting that this technique could be easily adapted as a semi-quantitative method for the certification of virusfree materials. In chronically infected bulbs of cultivar Blanco Mendocino, all cloves seem to be equally affected, implying that printing of a single clove could be used as a practical method to detect diseased seed-bulbs or to perform epidemiological studies with the $\mathrm{C} 6 \mathrm{CP}$ antiserum. Nevertheless, more studies including larger number of bulbs, additional garlic varieties, and different plant growth stages must be carried out before implementing this proposal. Independently of the sampling method ultimately adopted, it is worth noticing that tissue printing could advantageously compete with DAS-ELISA due to its relatively low cost and high detection sensitivity (5).

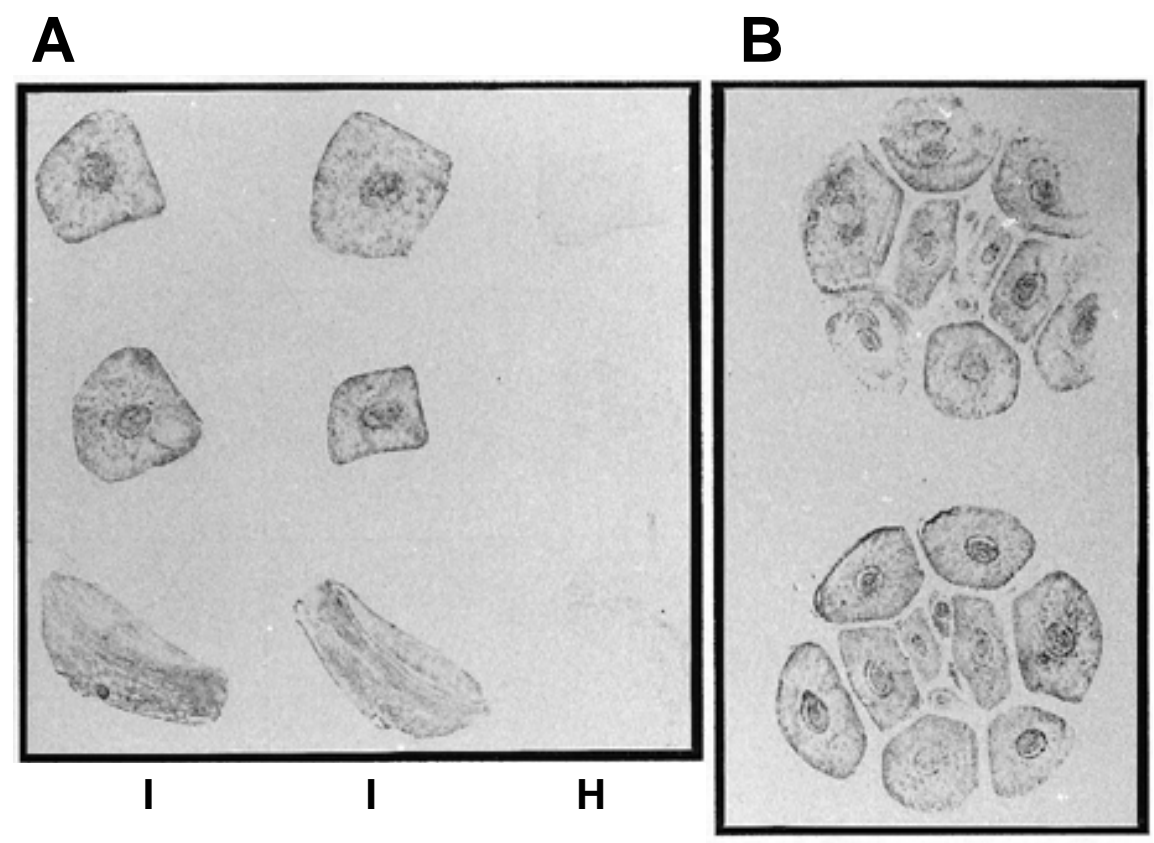

Fig. 4. Immunochemical detection of garlic virus A (GarV-A) by tissue printing immunoassays using the $\mathrm{C} 6 \mathrm{CP}$ antiserum. (A) tissue printing of cloves sampled from different infected and healthy garlic plants. $\mathrm{H}=$ cloves from healthy plants; $\mathrm{I}=$ cloves from infected plants. (B) Tissue printing of a single bulb obtained from a chronically infected garlic plant. 


\section{ACKNOWLEDGMENTS}

M. Helguera and F. Bravo-Almonacid are fellows of CONICET; K. Kobayashi and P. D. Rabinowicz are fellows of Fundación Antorchas and University of Buenos Aires, respectively; and V. Conci and A. Mentaberry are Research Scientists of INTA and CONICET, respectively.

\section{LITERATURE CITED}

1. Ausubel, F. M., Brent, J. A., Kingston, R., Moore, D., Seidman J. D., Smith, J. A., and Struthl, K. 1994. Current Protocols in Molecular Biology. Karen Joanne ed. John Wiley \& Sons, New York.

2. Barg, E., Lesemann, D. E., Vetten, H. J., and Green, S. K. 1994. Identification, partial characterization, and distribution of viruses infecting Allium crops in South and Southeast Asia. Acta Hortic. 358:251-258.

3. Bradford, M. M. 1976. A rapid and sensitive method for the quantitation of microgram quantities of protein utilizing the principle of protein dye binding. Anal. Biochem. 72:248254.

4. Brandes, J., and Wetter C. 1959. Classification of elongated plant viruses on the basis of particle morphology. Virology 8:99-115.

5. Bravo-Almonacid, F., Haim, L., and Mentaberry, A. N. 1992. Rapid immunological detection of potato viruses in plant tissue squashes. Plant Dis. 76:574-578.

6. Clark, M. F., and Adams, A. N. 1977. Characteristics of the microplate method of enzyme-linked immunosorbent assay for the detection of plant viruses. J. Gen. Virol. 34:475-483.

7. Conci, V. C., and Nome, S. F. 1991. Virus free garlic (Allium sativum L.) plants obtained by thermotherapy and meristem tip culture. J. Phytopathol. 132:186-192.

8. Conci, V. C., Nome, S. F., and Milne, R. G. 1992. Filamentous viruses of garlic in Argentina. Plant Dis. 76:594-596.

9. Dellecole, B., and Lot, H. 1981. Viroses de 1'ail: I Mise en évidence et essais de caractérisation par immunoélectromicroscopie d'un complexe de trois virus chez différentes population d'ail atteintes de mosaïque. Agronomie 1:763-769.

10. Frenkel, M. J., Ward, C. W., and Shukla, D. D. (1989). The use of $3^{\prime}$ non-coding nucleotide sequences in the taxonomy of potyviruses: application to watermelon mosaic virus 2 and soybean mosaic virus-N. J. Gen. Virol. 70:2775-2783.

11. Harlow, W., and Lane, D. 1988. Page 349 in: Antibodies: A Laboratory Manual. Cold Spring Harbor Laboratory Press, New York.

12. Hull, R. 1985. Purification, biophysical and biochemical characterization of viruses with especial reference to plant viruses. Pages 1-14 in: Virology: A Practical Approach. B. W. J. Mahy, ed. IRL Press, Oxford.

13. Kanyuka, K. V., Vishnichenko, V. K., Leva, K. E., Kondrikov, D. Y., Ryabov, E. V., and Zavriev, S. K. 1992. Nucleotide sequence of shallot virus X RNA reveals a 5'-proximal cistron closely related to those of potexviruses and a unique arrangement of the 3'proximal cistrons. J. Gen. Virol. 73:25532560 .

14. Kobayashi, K., Rabinowicz, P., Bravo-Almonacid, F., Helguera M., Conci, V., Lot, H., and Mentaberry, A. N. Coat protein gene sequences of garlic and onion isolates of the onion yellow dwarf potyvirus (OYDV). Arch. Virol. 141: 2277-2287.

15. Koch, M., and Salomon, R. 1994. Serological detection of onion yellow dwarf virus in garlic. Plant Dis. 78:785-788.

16. Maniatis, T., Fritsch, E. F., and Sambrook, J. 1988. Molecular cloning: A Laboratory Manual. Cold Spring Harbor Laboratory Press, New York.

17. Milne, R. G., and Luisoni, E. 1977. Rapid immune electron microscopy of virus preparations. Methods Virol. 6:265-281.

18. Murphy, F. A., Fauquet, C. M., Bishop, D. H. L., Ghabrial, S. A., Martelli, G. P., Mayo, A., and Summers, M. D. 1995. Virus taxonomy. 6th Rep. Int. Commit. Taxonomy Viruses. Springer-Verlag, Vienna.

19. Murphy, J. F., Rhoads, R. E., Hunt, A. G., and Shaw, J. G. 1990. The VPg of tobacco etch virus RNA is the $49-\mathrm{kDa}$ proteinase or the Nterminal $24-\mathrm{kDa}$ part of the proteinase. Virology $178: 285-288$.

20. Nagakubo, T., Kubo, M., and Oeda, K. 1994. Nucleotide sequences of $3^{\prime}$ regions of two major viruses from mosaic-diseases in garlic: molecular evidence of mixed infection by a potyvirus and a carlavirus. Phytopathology
84:640-645.

21. Sanger, F., Nicklen, S., and Coulson, A. 1977. DNA sequencing with chain-terminating inhibitors. Proc. Natl. Acad. Sci. USA 74:54635467.

22. Sumi, S., Tsuneyoshi, T., and Furutani, H 1993. Novel rod-shaped viruses isolated from garlic, Allium sativum, possessing a unique genome organization. J. Gen. Virol. 72:9-14

23. Tsuneyoshi, T., and Sumi, S. 1996. Differentiation among garlic viruses in mixed infections based on RT-PCR procedures and direct tissue blotting immunoassays. Phytopathology 86:253-259.

24. Van Dijk, P. 1993. Carlavirus isolates from cultivated Allium sp. represent three viruses. Neth. J. Plant. Pathol. 99:233-257.

25. Van Dijk, P. 1993. Survey and characterization of Potyviruses and their strains of Allium sp. Neth. J. Plant. Pathol. 99 Supplement 2:1-48.

26. Van Dijk, P., and Van der Vlugt, R. A. A 1994. New mite-borne virus isolates from rakkyo, shallot and wild leek species. Eur. J. Plant. Pathol. 100:269-277.

27. Van Dijk, P., Verbeck, M., and Bos, L. 1991. Mite-borne virus isolates from cultivated $\mathrm{Al}$ lium sp. and their classification into two new rymoviruses in the family Potyviridae. Neth. J. Plant. Pathol. 97:381-399.

28. Walkey, D. G. A. 1990. Virus Diseases. Pages 191-212 in: Onions and Allied Crops, Volume II. Rabinowitch, H. D., and Brewster, J. L., eds. CRC Press, Boca Ratón, FL.

29. Walkey, D. G. A., and Antill, D. N. 1989 Agronomic evaluation of virus-free and virus infected garlic. J. Hortic. Sci. 64:53-64.

30. Walkey, D. G. A., Webb, M. J. W., Bolland, C. J., and Miller, A. 1987. Production of virusfree garlic (Allium sativum L.) and shallot $(A$ ascalonicum L.) by meristem-tip culture. J. Hortic. Sci. 62:211-220.

31. Yamashita, K. 1993. Purification and serology of garlic mite-borne mosaic virus (GMbMV). (Abstr.) Ann. Phytopathol. Soc. Jpn. 59:57.

32. Yamashita, K., Sakai, J., and Hanada, K. 1995. Leek yellow stripe virus (LYSV) isolated from garlic and its relationship to garlic mosaic virus (GMV). (Abstr.). Ann. Phytopathol. Soc. Jpn. 61:273. 